Canadian

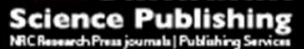

Canadian Journal of Civil Engineering Revue canadienne de génie civil

\title{
EFFICACY OF FOREST BASED ASH AS A SUPPLEMENTARY CEMENTING MATERIAL FOR CONCRETE
}

\begin{tabular}{|r|l|}
\hline Journal: & Canadian Journal of Civil Engineering \\
\hline Manuscript ID & cjce-2016-0351.R2 \\
\hline Manuscript Type: & Article \\
\hline Date Submitted by the Author: & 07-May-2017 \\
\hline Complete List of Authors: & $\begin{array}{l}\text { Setayeshgar, Parisa; University of Alberta, Civil and Environmental } \\
\text { Engineering } \\
\text { Boluk, Yaman; University of Alberta, Civil and Environmental Engineering } \\
\text { Bindiganavile, Vivek; University of Alberta, Civil and Environmental } \\
\text { Engineering }\end{array}$ \\
\hline $\begin{array}{r}\text { Is the invited manuscript for } \\
\text { consideration in a Special } \\
\text { Issue? : }\end{array}$ & N/A \\
\hline Keyword: & $\begin{array}{l}\text { MP - concrete < Engineering Materials, structure - concrete < Struct. Eng. \& } \\
\text { Constr.Mate }\end{array}$ \\
\hline &
\end{tabular}




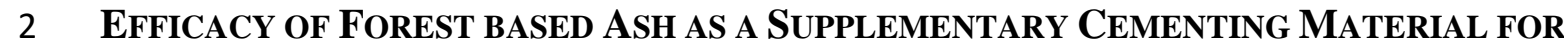

3 Concrete

4 Parisa Setayeshgar ${ }^{1}$, Yaman Boluk ${ }^{2}$ and Vivek Bindiganavile ${ }^{3_{*}}$

5 Department of Civil and Environmental Engineering, The University of Alberta, Edmonton, AB Canada T6G 1H9

6 1. Formerly, Graduate Research Assistant

7 2. Professor

8 3. Associate Professor

\section{Abstract}

This

paper presents

a feasibility

study

on the effects

of

14 forest-based ash (FBA) on the mechanical performance of concrete. Four such samples were obtained from the pulp and paper industry as the residual byproduct of their hog fuel. They were analysed for grain size distribution, density, morphology and oxide content. Subsequently, the ash

17 was employed as a cement substitute (up to $20 \%$ by mass) and the resulting concrete was examined

18 for mechanical properties. Results show that all four FBA samples were coarser than Portland

19 cement with mean particle size around 100-1000 microns. Further, X-ray florescence showed that

20 the FBA samples were predominantly composed of $\mathrm{CaO}$, with significant amounts of $\mathrm{SO}_{3}$ and

21 alkali oxides at levels which exceed maximum limits allowed for the latter by ASTM. This poses

22 concerns on durability. Nevertheless, based on short term compressive and tensile performance

23 alone, this study shows that FBA could replace up to $15 \%$ by mass of cement.

*Contact Author, Email: vivek@ualberta.ca, Tel No: 780.492.9661 


\section{Introduction}

26 The work reported here is a study conducted to ascertain the mechanical performance of concrete

27 containing samples of forest based ash (FBA) as a supplementary cementing material towards

28 partial replacement of Portland cement. The FBA was obtained by burning forest wood barks -

29 both hard and soft wood - and other wood residues, that are deemed a waste and so used as hog

30 fuel by the pulp and paper industry across Alberta in Western Canada. This study focused firstly,

31 on characterizing the ash samples for physical and chemical properties and secondly, on the short

32 term mechanical performance of concrete made with the ash as a supplementary cementing

33 admixture.

34 The possibility of gainfully using agricultural wastes in concrete mixtures, both to solve the waste

35 disposal problem and to get a cost advantage in concrete production, has caught the attention of

36 researchers in the last couple of decades. Accordingly, sugarcane bagasse ash (SCBA), rice husk

37 ash (RHA) and coconut husk ash (CHA) have variously been examined for their pozzolanic potential (Rabi et al. 2009; Paula et al. 2010; Fairbairn et al. 2012). In all cases, results from tests

39 with mortars indicate the viability of partial substitution of cement by up to $20 \%$ of the ash 40 considered. Chusilp et al. (2009) reported that sugarcane bagasse ash when used as a pozzolanic 41 material in concrete imparts acceptable strength, lower heat evolution, and a reduced water 42 permeability with respect to the reference mixture containing Portland cement only. Concrete 43 containing $20 \%$ ground bagasse ash had the highest compressive strength at over $110 \%$ of the 44 reference mixture (Srinivasan et al. 2010; Radke et al. 2012). Further, Castaldelli et al. (2013) 45 reported SCBA as a feasible starting material for preparing alkali-activated geopolymers. 
47 With rice husk ash, cement replacement at between 10-20\% depending on mixture design, led to 48 higher compressive strength in concrete (Ramasamy 2010; Foletto et al. 2006 and Ganesan et al. 49 2008). Similarly, Ramezanianpour et al. (2009) showed that concrete incorporating RHA resulted 50 in higher compressive strength, higher tensile strength and superior modulus of elasticity at various 51 ages compared with that of the reference unblended concrete.

52 There appears to be limited information available on the potential for ash sourced from using forest 53 wastes such as wood barks and low quality wood chips (Chowdhury et al. 2014 and Grau et al. 54 2015). The mixture of bark, low quality wood chip shavings, sawdust and other wood waste which 55 are burned as fuel by pulp mills is called "hog fuel". The composition of hog fuel is not well 56 defined and it depends upon the local wood species and the presence of wood based industries 57 such as saw mills and pulp mills. A considerable amount of such ash is produced in Alberta when wood bark and chips that are deemed as lower quality and hence unfit for use in the pulp and paper 59 industry, are used instead as fuel. Therefore, this study was undertaken principally to assess the 60 effect of using such ash as a pozzolanic admixture in concrete. Four samples of forest $\underline{b} a s e d$ ash 61 (FBA) sourced from the pulp and paper industry in Alberta were examined. These samples were 62 first characterized for their physical properties and chemical composition and thereafter, 63 incorporated as partial replacement of Portland cement in concrete to examine their effect on the 64 key mechanical properties of concrete.

67 Concrete cylinders were prepared with varying amounts of forest based ash. Four different types 68 of ash derived from burning forest waste in Alberta's pulp and paper mills were used. For each 
69 type of FBA, Portland cement was replaced at 5 to $20 \%$ by mass in $5 \%$ intervals. A reference 70 mixture was also prepared containing only Portland cement, sand, aggregates and water. Thus, in

71 all, seventeen mixtures were examined and the samples were subjected to compression and split 72 tension tests.

\section{Constituent Materials}

75 Type GU Portland cement conforming to CSA A3001-13 (ASTM C150), locally available coarse aggregate and sand conforming to ASTM C33 were used to prepare the concrete specimens in this

77 study. The salient properties of these materials were as follows: The Type GU cement had a bulk

78 density of $1450 \mathrm{~kg} / \mathrm{m}^{3}$; the maximum particle size for the coarse aggregate was $8 \mathrm{~mm}$ and its bulk 79 density was $1710 \mathrm{~kg} / \mathrm{m}^{3}$; the fine aggregate had a bulk density of $1900 \mathrm{~kg} / \mathrm{m}^{3}$ and the four types of 80 forest based ash namely, FBA 1 through FBA 4 had a respective bulk density of $405 \mathrm{~kg} / \mathrm{m}^{3}, 520$ $81 \mathrm{~kg} / \mathrm{m}^{3}, 470 \mathrm{~kg} / \mathrm{m}^{3}$ and $320 \mathrm{~kg} / \mathrm{m}^{3}$. The forest based ash samples were created by firing the hog fuel 82 while generating heat and steam at pulp mills. Hog fuel generally comes from a variety of sources_-sawmill bark (mostly softwood), hardwood bark and scraps from the bush that result

84 from the chipper operations, old hay from surrounding farms and, fibres from the effluent clarifier 85 (ie. both primary and secondary sludge). In general, there is always considerable variability in the 86 biological source for forest based ash. The best that one can ascertain is that the source vegetation 87 came from within the Province of Alberta. The forest based ash samples were obtained after 88 burning the aforementioned waste as fuel in the paper mills at between $400-470^{\circ} \mathrm{C}$. 


\section{Preparation of Fresh and Hardened Concrete Specimens}

92 The mixtures were designed to achieve a compressive strength of $30 \mathrm{MPa}$ at 28 days and a workability corresponding to a slump of $25-50 \mathrm{~mm}$. The water to cement ratio was selected at 0.5

94 and the mixture proportions are listed in Table 1. The target slump was not high since this study was also intended to compare with a series containing sugarcane bagasse ash for applications in India (Setayeshgar 2015). Concrete cylinders of length $150 \mathrm{~mm}$ and $75 \mathrm{~mm}$ diameter were cast. As shown later, the mean particle size for all samples of ash was found to be one order of magnitude bigger than that for Portland cement. Hence, it was deemed better to let the ash mix 99 with the rest of the dry constituents, ahead of introducing water. Accordingly, the coarse aggregate was first poured in the mixer and then sand, cement and ash were added in that order and mixed

101 firstly as dry powder in the mixer for 2 minutes. Subsequently, the amount of water per the mix 102 design was added to the dry mixture and the resulting mixture was agitated together for a further 1032 minutes. The assembled molds were filled with the cement concrete mixture in 3 layers and 104 compacted using a table vibrator. The cylinders were removed from the molds after 24 hours of casting and cured until 28 days in a controlled environment chamber maintaining a humidity of

$106100 \%$ and a temperature of $23 \pm 2{ }^{\circ} \mathrm{C}$. The concrete specimens were designated CFBA in order to 107 distinguish them from the ash contained therein (FBA).

\section{Testing of Fresh and Hardened Concretes}

111 For each mixture prepared, the slump and air content were evaluated as per ASTM C143 and 112 ASTM C231, respectively. The concrete cylinder in compression was instrumented with lateral 
113 and vertical LVDTs that were in turn connected to a data acquisition system with $1 \mathrm{~Hz}$ frequency.

114 Thus, the modulus of elasticity and the Poisson's ratio were evaluated alongside. The compression

115 test was per ASTM C496 while the splitting tension test was done as per ASTM C469.

\section{Results and Discussion}

\section{Physical and Chemical Characterization of FBA}

119 The bulk density of these four samples of FBA were evaluated prior to mixing and have already 120 been listed above. The samples were analyzed for grain size distribution using a laser diffraction 121 mastersizer followed by scanning electron microscopy (SEM) to examine their morphology. 122 Chemical characterization involved identification and quantification of the constituent oxides, 123 through energy-dispersive X-ray spectroscopy (EDX), X-ray diffraction (XRD) and X-ray 124 fluorescence (XRF).

125 Figure 1 shows the X-ray diffraction traces (XRD) of the four different types of FBA used in this 126 study. Table 2 summarizes the various oxides found in these FBA samples. While there is no

127 standard that pertains directly to the cementing ability of forest based ash, a guideline is offered 128 through ASTM C618 (2013), wherein certain performance based limits are placed on the 129 composition. In particular, given the high $\mathrm{CaO}$ content of the FBA samples seen in this study, a 130 comparison is made with Class N Pozzolan and Class C Fly Ash. These limits are captured in 131 Table 2, alongside the oxide composition of the FBA samples from this study. Note that the sum 132 of the key acidic oxides namely, silica, alumina and iron oxides in the four samples of FBA 133 examined here is lower than the minimum allowable amount, per ASTM C618. On the other hand, 134 the FBA samples had higher alkali content $\left(\mathrm{Na}_{2} \mathrm{O}+\mathrm{K}_{2} \mathrm{O}\right)$ and higher $\mathrm{SO}_{3}$ content than the limits 
135 imposed in ASTM C618. The present findings echo those seen by others (Etiegne and Campbell 136 1991; Naik et al. 2001; Udoeyo et al. 2006; Abdullahi 2006). All four FBA samples revealed high $137 \mathrm{CaO}$ content and FBA 4 had over $60 \% \mathrm{CaO}$. While the range of possible oxide content from 138 Alberta's pulp mills is currently being examined by the authors, the present study indicates that as 139 against being strictly pozzolanic, the FBA is likely latent hydraulic in nature with weak pozzolanic 140 reactivity.

141 Also, the presence of alkalis exceeds the allowable maximum limit. That may result in triggering 142 alkali-silica reaction with susceptible aggregates. However, Zerbino et al (2012) noted that if the 143 ash particles were smaller than 75 microns, the potential of alkali silica reaction would be 144 significantly minimized, making the ash suitable for concrete application. Further, it was seen that 145 in all four cases (FBA 1 through 4), the chemicals portlandite, arcanite, quartz and calcite exhibited 146 distinct peaks as compared to the other minerals. The XRD output shows that among the 147 constituent phases, quartz and calcite have maximum crystallinity. Some of the minerals identified 148 are the same as that for the Portland cement clinker such as arcanite. Others are the same as seen 149 in blended Portland cement, such as calcite, quartz and hematite. Still others resemble those found 150 in hydration products, such as portlandite (Aranda et al. 2012). As expected, only the crystalline 151 phases were detected through XRD. In order to detect the amorphous constituents and quantify the 152 oxides identified, EDX and XRF were done.

153 Table 3 shows the percentage of various elements that were found through EDX tests in the four 154 different samples of forest based ash: FBA 1, FBA 2, FBA 3 and FBA 4. In each case, the Calcium, 155 Oxygen and Carbon are dominant, suggesting the presence of $\mathrm{Ca}(\mathrm{OH})_{2}$ and $\mathrm{Ca}\left(\mathrm{CO}_{3}\right)$. Further, 156 significant amounts of potassium and silicon were found. It may be inferred that the minerals 
157 portlandite, arcanite, calcite and quartz appear to be more predominant than the other minerals 158 listed.

Results by previous researchers (Folleto et al. 2006; Larbi et al. 2010; Ramesanianpour et al. 2009) show that the main constituent in rice husk ash is silica, typically $85-88 \%$; that RHA also contains some minor oxides such as alkalis, sulphate and portlandite. Similarly, in SCBA, silica is the most

162 predominant oxide (Paya et al. 2002). Such studies also showed that the silica remained in the 163 amorphous form at temperatures between $450-700^{\circ} \mathrm{C}$ for 3 to 4 hours of husk burning. Since the 164 crystalline forms of silica have less reactivity than the amorphous one, it is essential that rice husks 165 burnt under temperature of $850^{\circ} \mathrm{C}$. In Alberta's pulp and paper mills, the burning temperature of 166 forest based ash is around $400-470^{\circ} \mathrm{C}$.

In order to understand the source composition of the hog fuel, an elemental analysis on forest based ash from Finland was referred to (Sarela et al. 2005). That study, summarized in Table 4, includes

170 bark and wood from birch, spruce and pine - all very common to Alberta's forest as well. The 171 compositions of other likely hog fuel sources such as old hay from surrounding farms or fibres 172 from the effluent clarifier (primary and secondary sludge) are not listed. The K/Na elemental ratios 173 for FBA samples in this study is shown in Table 5. Comparing between Tables 4 and 5, it can be 174 argued that FBA 4 has the least and FBA 2 has the most bark constituents. It also implies that 175 FBA 3 was second in terms of bark constituents.

177 Further, the ash samples were examined under a Scanning Electron Microscope to observe the size 178 and morphology of the constituent particles. It is seen from the micrographs in Figure 2 that most 
179 particles were larger than 100 microns. Whereas particles in FBA 1 were mostly spherical, those 180 in FBA 2 were variously spongy or shaped like needles. Particles of FBA 3 were both spherical 181 and sometimes flat as sheets and finally in FBA 4, the particles were seen to be variously spherical, 182 spongy and arranged into sheets.

183 The ash samples were analyzed for grain size distribution using a mastersizer instrument. This 184 device employs laser diffraction and measures the particle size distribution through the angular 185 variation in the intensity of light scattered when a laser beam passes through a dispersed particulate 186 sample. The angular scattering intensity is then analyzed to calculate the size of the particles 187 responsible for creating the scattering pattern.

It is clear from Figure 3, that ash samples FBA 1 and FBA 4 were somewhat finer than the other 189 two namely, FBA 2 and FBA 3. Among them, FBA 1 was the finest and FBA 2 was the coarsest in particle size distribution. One can explain the particle size based on the composition of ashes.

191 When the biomass power plants with wood and wood residues came into operation, fouling of 192 convection passes and severe deposits on grates and in fluidized beds were observed, due to 193 stickiness of particles. These wood residues, particularly bark, characteristically contain high 194 levels of potassium and other alkalis. They vaporize or react with other elements as they pass 195 through the boiler, partially condensing from the liquid phase and growing to form sticky deposits 196 on metal and refractory surfaces (Miles et al. 1996). The effect of chemical composition, in 197 particular potassium, sodium and chloride on the stickiness of ash deposits were analyzed in the 198 case of wood residues from kraft pulping (black liquor) firing (Reeve et al. 1983).

199 Note from Table 3, that when the elemental analysis was conducted across all samples, the 200 potassium content for FBA 4 was too low to register. The same was confirmed alternatively 
201 through XRF whereby as listed in Table 2, it is noted that the lowest $\mathrm{K}_{2} \mathrm{O}$ content was with FBA

202 4. In addition to the molar ratio between $\mathrm{K}$ and $\mathrm{Na}$, Table 5 presents also the mean particle size as

203 observed in the four FBA samples. From Table 4, note that typically, bark has a K/Na ratio of 26

204 while wood has a corresponding ratio of 13. Particle stickiness has been well studied in kraft

205 recovery boilers (Reeve et al. 1988). Those studies indicate that increasing the mole ratio of

$206 \mathrm{~K} /(\mathrm{Na}+\mathrm{K})$ leads to a drop in the melting point of the ash particles and so makes them sticky. This

207 in turn leads to adhesion and particle growth. Since bark is potassium rich, it is always desirable

208 to control the bark content in the hog fuel to minimize the $\mathrm{K} /(\mathrm{Na}+\mathrm{K})$ ratio and in turn reduce the

209 mean particle size. An excess of bark in the hog fuel therefore leads to more stickiness among the

210 particles that consequently results in coarser particle size distribution. Among the ash samples

211 here, FBA 4 had the least K/Na ratio while FBA 2 had the highest K/Na ratio. This ties in with the

212 particle size distribution shown in Figure 3.

213 Note that all four ash samples here were significantly coarser than Portland cement. On the other

214 hand, various other agro-sourced ash have been seen to be finer in comparison. For instance, the

215 particle size distribution in SCBA was between 1-100 $\mu \mathrm{m}$ with mean size at $35 \mu \mathrm{m}$ (Paya et al.

216 2002; Ganesan et al. 2007) while -rice husk ash is typically between 1 to $8 \mu \mathrm{m}$ (Yuzer 2013; Shatat

217 2014). The finer the particles, the better the pozzolanic efficiency. The authors are in discussion

218 with pulp and paper mills in order to further explore the possibility for engineering the particle

219 size distribution for FBA through suitable choice of hog fuel composition. For the present, after

220 examining the results of the physical and chemical analysis of the ash samples alone, FBA 4 was

221 thought to be best suited of the four FBA samples when used as a supplementary cementing

222 material. 


\section{Properties of Fresh Concretes}

225 Table 6 lists the slump and air content as measured for the fresh concrete prepared with the 226 different amounts of each type of FBA. As seen therein, FBA 1, FBA 2 and FBA 3 did not 227 adversely affect the slump. Perhaps due to its predominantly spherical particles, higher amounts 228 of FBA 1 leads to an increase in the slump. Whereas FBA 2 and FBA 3 had coarser particle size 229 distribution and were seen to increase the slump at low dosage, the predominantly non spherical 230 shape of their particles likely leads to a progressive reduction in slump at higher dosage. Note from 231 Figure 3 and Table 5 that of the four ash samples, FBA 4 had the smallest mean particle size. Also, 232 it was rich in $\mathrm{CaO}$ content, so that it was more likely than others to readily hydrate. All of which 233 is reflected in the decrease in slump recorded with this ash sample. As seen further in Table 6, the 234 four FBA samples did not adversely affect the air content in fresh concrete. While outside the 235 scope of the present study, it is nevertheless imperative in order to ensure freeze-thaw resistance 236 that further quantification of air content be made as the concrete matures in order to verify the 237 stability of the air-void network.

\section{Properties of Hardened Concretes}

\section{Compressive Strength}

240 The compressive strength for each mixture as evolving over 28 days of curing is listed in Table 7.

241 This data is plotted in Figure 4 to reflect the evolution with time. Figure 5 shows the compressive 242 strength at 28 days for the various mixtures examined here. It appears that of the four samples of 243 ash investigated here, FBA 4 imparts the highest strength to the concrete at 28 days. Note that the 244 compressive strength of mixtures containing FBA 4 is more than or equal to that of the reference 245 mixture up to $15 \%$ cement replacement. On the other hand, FBA 3 did not significantly alter the 
246 compressive strength when replacing Portland cement by up to $15 \%$ by mass. However, in case of 247 FBA 1 and FBA 2, the strength drops considerably - between 20-30\% with respect to the reference 248 mixture containing Portland cement alone - even at 5\% cement replacement. Even so, a dramatic 249 drop was observed only beyond $15 \%$ mass replacement. When comparing the present findings 250 with those from the literature, it should be borne in mind that the hog fuel composition is specific 251 to the source vegetation and local soil composition. As stated earlier, this in turn plays an important 252 role in oxide content of the resultant FBA. Nonetheless, studies by Udoeyo et al. (2006), Naik et 253 al. (2001) and Abdullahi (2006) reveal a drop in compressive strength with an increase in the ash 254 content. Yet, a blend of equal amounts of forest based ash and fly ash from coal-fed thermal power 255 plants appears to increase the compressive strength for total ash content up to $35 \%$ of the binder 256 (Naik et al. 2001). In all these studies, it is clear that between 10-15\% by mass of Portland cement 257 may be replaced with FBA. Beyond this dosage, a more rapid decrease in strength is seen. 
260

261

262

263

264

265

266

267

268

269

270

271 in the binder.

272

273

274

275

276

277 performance under splitting tension. On the one hand, note that FBA 2 was the coarsest with the

278 lowest $\mathrm{CaO}$ content and, this may be linked to consistently lower tensile strength as well as elastic

279 modulus. It is likely that the coarser particle size in all the FBA, as opposed to that of Portland 280 281

\section{Tensile Strength}

The splitting tensile strength of the mixtures as ascertained per ASTM C496 (2011) is listed in Table 8. As with the compression data, the evolution of strength over a 28 day curing period is shown in Figure 6. Further, the 28-day strength as evaluated with varying amounts of FBA is shown in Figure 7 for each ash sample. Unlike with compressive strength wherein smaller amounts of FBA 3 or FBA 4 led to an increase over that of the reference mixture, in case of tensile strength, the addition of FBA was seen to decrease it for all four ash samples. Others have found similarly that the tensile strength drops with introducing FBA into concrete. Nevertheless, as seen with their performance under compression, here too FBA 4 was the best performing ash with lower drops in tensile strength as compared to the reference mixture. Once again, Naik et al. (2001) noted an increase in tensile strength when the forest based ash is blended with fly ash up to a total of $35 \%$

\section{Modulus of Elasticity and Poisson's Ratio}

The modulus of elasticity, $E_{c}$, and the Poisson's ratio, $\mu$, were evaluated at 28 days, together with the compressive strength per ASTM C469 (2014). The data is listed in Table 9 and the modulus of elasticity is plotted in Figure 8. Not surprisingly, the modulus of elasticity mimics the cement, leads to a weaker interfacial transition zone that is more perceptible with tensile strength and the elastic modulus but is less so with compressive strength. Of the four samples examined 
282 here, two factors likely contribute to the superior performance of FBA 4. First, this ash sample 283 possessed the lowest mean particle size. Second, FBA 4 also had higher CaO content. Together, 284 the two likely contribute to latent hydraulic and weak pozzolanic reactivity.

285 As stated earlier, the authors could not ascertain precisely the origin of the biomass that led to 286 these ash samples, other than that they are from Alberta based forests. Nevertheless, the ash 287 samples were examined for physical properties and chemical composition. Subsequently, they 288 were incorporated as a cement substitute into concrete mixtures that were further evaluated for 289 fresh and hardened properties. Although long term durability was outside the scope of this study, 290 the levels of alkali oxides, specifically $\mathrm{Na}_{2} \mathrm{O}$ and $\mathrm{K}_{2} \mathrm{O}$ found in this study strongly compels a 291 concerted investigation on forest based ash for their alkali-silica reactivity before recommending 292 them unreservedly for utilization in concrete. Nonetheless, based on the results of this study, the 293 specific findings are as follows: 
294 1. The particle size analysis shows that all four samples of ash had mean particle size larger than 295100 microns and so, they were about one order of magnitude coarser than Portland cement. A 296 variety of particle shapes could be identified.

297 2. The forest based ash samples have a higher $\mathrm{CaO}$ content when compared with conventional 298 coal-based fly ash. At the same time, they had higher alkali content but lower acidic oxide 299 content than is acceptable in coal-based fly ash or Class N pozzolan. Specifically, as the ratio 300 content and among the finest particle size distribution.

3. When used as a cement substitute, FBA 4 performed most efficiently among the four ash samples, across all mechanical parameters evaluated here. An optimal dosage was found to be $10-15 \%$ of cement replacement.

Acknowledgements:

308

This study was funded by the Biorefining Conversions Network (BCN), through Alberta Innovates Bio-Solutions.

\section{References:}

314 Abdullahi, M. 2006. Characteristics of Wood ASH/OPC Concrete, Leonardo Electronic Journal 315 of Practices and Technologies, Issue 8: 9-16, ISSN 1583-1078. 
316 Amin, N. 2011.Use of Bagasse Ash in Concrete and Its Impact on the Strength and Chloride

317 Resistivity, Journal of Materials in Civil Engineering, 23(5): 717-720.

318 Aranda, M.A.G., Torre, A.G.D. 2012. Rietveld Quantitative Phase Analysis of OPC Clinkers, 319 Cements and Hydration Products, Journal of Applied Engineering Science, 2(15): 35-42.

320 Arioz, O. 2007. Effects of elevated temperatures on properties of concrete, Fire Safety Journal, $321 \quad 42: 516-522$.

322 ASTM C33/C33M 2013. Standard Specification for Concrete Aggregates, 2013, ASTM 323 International.

324 ASTM C150/C150M 2012. Standard Specification for Portland Cement, ASTM International.

325 ASTM C231/C231M 2014. Standard Test Method for Air Content of Freshly Mixed Concrete by 326 the Pressure Method, ASTM International.

327 ASTM C143/C143M 2012. Standard Test Method for Slump of Hydraulic-Cement Concrete, 328 ASTM International.

329 ASTM C496/C496M 2011. Standard Test Method for Splitting Tensile Strength of Cylindrical 330 Concrete Specimens, ASTM International.

331 ASTM C469/C469M 2014. Standard Test Method for Static Modulus of Elasticity and Poisson's 332 Ratio of Concrete in Compression, ASTM International, Designation: C469/C469M

333 ASTM C618 2015. Standard Test Method for Coal Fly Ash and Raw or Calcined Natural Pozzolan 334 for Use in Concrete, ASTM International.

335 Bye, G.C., Portland cement composition, production and properties, 2nd edition, Thomas Telford. 336 Castaldelli,V.N., Akasaki,J.L., Melges, J.L., Tashima, M.M., Soriano, L., Borrachero, M.V., 337 Monzó, J. and Payá,J. 2013. Use of Slag/Sugar Cane Bagasse Ash (SCBA) Blends in the 338 Production of Alkali-Activated Materials, Journal of Materials, 6: 3108-3127. 
339 Chowdhury, S., Maniar, A. and Suganya, O.M. 2014. Strength development in concrete with wood 340 ash blended cement and use of soft computing models to predict strength parameters, Journal of 341 Advanced Research, 6(6), 907-913.

342 Chusilp, N., Likhitsripaiboon, N. and Jaturapitakkul, C. 2009. Development of bagasse ash as a 343 pozzolanic material in concrete, Asian Journal on Energy and Environment, 10(03):149-159.

344 Cooper, P. A. and Balatinecz, J. J. and Flannery, S.J. 1999. Agricultural waste materials for 345 composites: A canadian realty, In proceedings of Centre for Management Technology global panel 346 based Conference, Kuala Lumpur, 18-19 October 1999.

347 Elsageer, M.A., Millard, S.G., Barnett, S.J. 2009. Strength development of concrete containing 348 coal fly ash under different curing temperature conditions, World of coal ash (WOCA) conference, 349 May 4-7, Lexington, KY, USA.

350 Etiégni L, Campbell AG. 1991. Physical and chemical characteristics of wood ash. Bioresource 351 Technology, 37: 173-178.

352 Fairbairn, E. M. R., Paula, T. P. D, Cordeiro, E G. C., Americano, B. B., Toledo Filho, R. D., 353 2012, Evaluation of partial clinker replacement by sugar cane bagasse ash: CO2 emission 354 reductions and potential for carbon credits, Ibracon structures and materials Journal, 5( 2) : 229355251.

356 Foletto, E.L., Gratieri, E., Oliveira, L.H.D., Jahn, S.L. 2006.Conversion of Rice Hull Ash into 357 Soluble Sodium Silicate, Journal of Materials Research, 9(3): 335-338.

358 Ganesan, K., Rajagopal, K. and Thangavel, K. 2008. Rice husk ash blended cement: Assessment 359 of optimal level of replacement for strength and permeability properties of concrete, Journal of 360 Construction and Building Materials, 22(8):1675-1683. 
361 Gorhan, G., Simsek, O. 2013. Porous clay bricks manufactured with rice husks, Journal of 362 Construction and Building Materials, 40: 390-396.

363 Grau, F., Choo, H., Hu, J. W. and Jung, J. 2015. Engineering Behavior and Characteristics of 364 Wood Ash and Sugarcane Bagasse Ash, Journal of Materials, 8(10): 6962-6977.

365 Harison A., Srivastava V. and Herbert A. 2014. Effect of Fly Ash on Compressive Strength of 366 Portland Pozzolona Cement Concrete, Journal of Academia and Industrial Research (JAIR), $367 \quad 2(8): 476-479$.

368 Husem, M. 2006. The effects of high temperature on compressive and flexural strengths of 369 ordinary and high-performance concrete, Fire Safety Journal, 41(2): 155-163.

370 Jumate, E., Manea, D.L. 2012. Application of X ray diffraction (XRD) and scanning electron 371 microscopy (SEM) methods to the portland cement hydration processes, Journal of Reviews in 372 Mineralogy \& Geochemistry, 74: 169-209.

373 Kawade, U.R., Rathi, V.R.Vaishali and Girge, D. 2013. Effect of use of Bagasse Ash on Strength 374 of Concrete, International Journal of Innovative Research in Science, Engineering and 375 Technology, 2(4): 1-8.

376 Krishna Rao, M.V., Shobha M. and Dakshina Murthy N.R. 2011. Effect of elevated temperature 377 on strength of differently cured concretes-an experimental study, Asian Journal of Civil 378 Engineering (Building and Housing), 12(1): 73-85.

379 Larbi, K.K. 2010. Synthesis of High Purity Silicon from Rice Husks. M.Sc. thesis, Department of 380 Materials Science and Engineering, University of Toronto, Toronto, ON.

381 Madurwar, M. V., Ralegaonkar, R. V., Mandavgane, S. A. 2013. Application of agro-waste for 382 sustainable construction materials: A review, Journal of Construction and Building Materials, 38, $383 \quad 872-878$. 
384 Miles, T.R., Baxter, L.L., Bryers, R.W., Jenkins, B.M. and Oden, L.L., 1996. Boiler Deposits from 385 Firing Biomass Fuels, Biomass and Bioenergy 10(2-3): 125-138.

386 Naik, T.R., Kraus, R.N. and Kumar, R. 2001. Wood ash: a new source of pozzolanic material, 387 Report No. CBU-2001-10, REP-435, ACI Maharastra Chapter, Mumbai, India.

388 Nair, D.G., Fraaija, A., Klaassen, A.A.K., Kentgens, A.P.M. 2008. A structural investigation 389 relating to the pozzolanic activity of rice husk ashes, Journal of Cement and Concrete Research, $39038(6), 861-9$.

391 Paula,M.O., Tinoco,I.F.F, Rodrigues,C.S., Saraz, J.A.S. 2010. Sugarcane bagasse ash as partial 392 Portland cement replacement material, Scielo Journal, 77(163): 47-54, ISSN 0012-7353.

393 Paya, J., Monzo,J., Borrachero, M.V., Pinzo'n, L.D. and Ordo'ñez, L.M. 2002. Sugar-cane 394 bagasse ash (SCBA): studies on its properties for reusing in concrete production, Journal of 395 Chemical Technology and Biotechnology, 77(3): 321-325.

396 Rabi, J. A., Santos, S. F., Tonoli, G. H. D. and Jr., H. S. 2009. Agricultural wastes as Building 397 Materials: Properties, Performance and Applications, In Building Materials: Properties, 398 Performance and Applications, Edited by Cornejo, D.N. and Haro, J.L., Nova Science Publishers, 399 Inc., 299-342.

400 Radke, B. 2012. Sugarcane bagasse ash waste, Biofuels and Agriculture- A Technical Overview, 401 In presentation of UNICAMP, Brazil, 5 June 2012.

402 Ramasamy, V. 2010. Compressive Strength and Durability Properties of Rice Husk Ash Concrete, 403 KSCE Journal of Civil Engineering, 16(1): 93-102, DOI: 10.1007/s12205-012-0779-2.

404 Ramezanianpour, A. A., Mahdi khani, M. and Ahmadibeni, Gh. 2009. The Effect of Rice Husk 405 Ash on Mechanical Properties and Durability of Sustainable Concretes, International Journal of 406 Civil Engineering, 7(2): 83-91. 
407 Ramirez, R.A., Garcia, P.M., Reyes, J.M., Juarez, D.C.A and Ponce, Y.G. 2012. The use of 408 sugarcane bagasse ash and lime to improve the durability and mechanical properties of compacted 409 soil blocks, Journal of Construction and Building Materials, 34: 296-305.

410 Recommended guidelines for concrete mix design, 1999, Bureau of Indian Standards, clause 3.8, 411 Appendix V, IS 10262-1982.

412 Reeve, D.W., Tran, H.N. and Barbarn. D. 1983. Formation of Kraft Recovery Boiler Superheater 413 Fireside Deposits, Pulp \& Paper Canada 84: 36-41.

414 Reeve. D. W., Tran, H.N. and Barham D. 1988. Sintering of Deposits and Its Impact on Plugging 415 in Kraft Recovery Units. Tappi Journal. 70 (4):109.

416 Saarela, K.E., Harju, L., Rajander, J., Lill, J.O., Heselius, S.J., Lindroos, A. and Mattsson, K. 2005.

417 Elemental analyses of pine bark and wood in an environmental study. Science of the Total 418 Environment Journal, 343(1): 231-241.

419 Setayeshgar P. 2015, Feasibility Studies on Usage of Agro-Forestry-Based Ash as a Cement 420 Replacement in Concrete, M.Sc. thesis, Department of Civil \& Environmental Engineering, 421 University of Alberta, Edmonton, AB.

422 Shatat, M.R. 2014. Hydration behavior and mechanical properties of blended cement containing 423 various amounts of rice husk ash in presence of metakaolin, Arabian Journal of Chemistry, In 424 Press.

425 Shetty, M.S. 1982. Concrete Technology (theory and practice), S.Chand publications, pg47-53, 78 426 and 112.

427 Srinivasan, R. and Sathiya, K. 2010. Experimental study on bagasse ash in concrete, International 428 journal for service learning in engineering, 5(2): 60-66, ISSN 1555-9033. 
429 Udoeyo, F.F., Inyang, H., Young, D.T. and Oparadu, E.E. 2006. Potential of Wood Waste Ash as 430 an Additive in Concrete, Journal of materials in civil engineering, 18(4): 605-611.

431 Vasuda Rao, S.V. and Tummalapudi, M. 2012. Performance of Rice Husk Ash Concrete at 432 Elevated Temperatures. International Journal of earth sciences and engineering, 5(3): 640-643, 433 ISSN 0974-5904.

434 Yuzer, N., Cinar, N., Akoz, F., Biricik, H., Gurkan, Y.Y., Kabay, N., Kizilkanat, A.B. 2013. 435 Influence of raw rice husk addition on structure and properties of concrete, Journal of Construction 436 and Building Materials, 44: 54-62.

437 Zerbino, R., Giaccio, G., Batic, O.R., Isaia, G.C. 2013. Alkali-silica reaction in mortars and 438 concretes incorporating natural rice husk ash, Journal of Construction and Building Materials, 36: $439796-806$. 
Table 1- Mixture Proportions of Concretes

\begin{tabular}{|c|c|c|c|c|c|}
\hline FBA/Binder & Cement $\left(\mathbf{k g} / \mathbf{m}^{\mathbf{3}}\right)$ & $\mathbf{F B A}(\mathbf{1}, \mathbf{2}, \mathbf{3}, \mathbf{4})$ & Water $\left(\mathbf{k g} / \mathbf{m}^{\mathbf{3}}\right)$ & Sand $\left(\mathbf{k g} / \mathbf{m}^{\mathbf{3}}\right)$ & Coarse \\
\hline Content & & $\mathbf{k g} / \mathbf{m 3})$ & & Aggregate $\left(\mathbf{k g} / \mathbf{m}^{\mathbf{3}}\right)$ \\
\hline $0 \%$ & 400 & 0 & 200 & 600 & 1200 \\
\hline $5 \%$ & 380 & 20 & 200 & 600 & 1200 \\
\hline $10 \%$ & 360 & 40 & 200 & 600 & 1200 \\
\hline $20 \%$ & 340 & 60 & 200 & 600 & 1200 \\
\hline
\end{tabular}

Table 2- Chemical Composition of Forest Based Ashes (ASTM C618, Bye 1999)

\begin{tabular}{|c|c|c|c|c|c|c|c|}
\hline \multirow{2}{*}{ Oxide: } & FBA 1 & FBA 2 & FBA 3 & FBA 4 & $\begin{array}{c}\text { Portland } \\
\text { cement }\end{array}$ & $\begin{array}{c}\text { Pozzolan } \\
\text { Class N }\end{array}$ & $\begin{array}{c}\text { Fly Ash } \\
\text { Class C }\end{array}$ \\
\cline { 2 - 8 } & $\begin{array}{c}\text { Average } \\
\mathrm{Wt} \%\end{array}$ & $\begin{array}{c}\text { Average } \\
\mathrm{Wt} \%\end{array}$ & $\begin{array}{c}\text { Average } \\
\mathrm{Wt} \%\end{array}$ & $\begin{array}{c}\text { Average } \\
\mathrm{Wt} \%\end{array}$ & $\begin{array}{c}\text { allowable } \\
\text { Wt\% limit }\end{array}$ & $\begin{array}{c}\text { allowable } \\
\text { Wt\% limit }\end{array}$ \\
\hline $\mathrm{Al}_{2} \mathrm{O}_{3}+\mathrm{Fe}_{2} \mathrm{O}_{3}+\mathrm{SiO}_{2}$ & 15.23 & 18.66 & 13.34 & 3.85 & & Min & Min \\
\hline $\mathrm{Alkalies}$ & 12.39 & 15.85 & 16.23 & 8.10 & $0.17-1.60$ & Max 1.50 & 50.00 \\
\hline $\left.\mathrm{K}_{2} \mathrm{O}, \mathrm{Na}_{2} \mathrm{O}\right)$ & 2.45 & 1.92 & 2.99 & & $0.07-0.40$ & & \\
\hline $\mathrm{Na}_{2} \mathrm{O}$ & 5.81 & 3.45 & 5.21 & 1.94 & $0.50-2.50$ & & \\
\hline $\mathrm{MgO}^{\mathrm{Al}}$ & 1.98 & 2.50 & 1.78 & 0.53 & $3.00-7.00$ & & \\
\hline
\end{tabular}




\begin{tabular}{|c|c|c|c|c|c|c|c|}
\hline $\mathrm{SiO}_{2}$ & 11.88 & 14.31 & 10.31 & 2.31 & $19.00-23.00$ & & \\
\hline $\mathrm{P}_{2} \mathrm{O}_{5}$ & 4.09 & 3.16 & 3.60 & 3.43 & & & \\
\hline $\mathrm{SO}_{3}$ & 25.60 & 28.03 & 31.02 & 18.47 & $2.50-3.50$ & Max 4.00 & Max 5.00 \\
\hline $\mathrm{K}_{2} \mathrm{O}$ & 9.94 & 13.93 & 13.24 & 8.10 & $0.10-1.20$ & & \\
\hline $\mathrm{CaO}$ & 36.00 & 29.99 & 29.72 & 63.03 & $63.00-67.00$ & & \\
\hline $\mathrm{TiO}_{2}$ & 0.22 & 0.28 & 0.19 & 0.22 & & & \\
\hline $\mathrm{MnO}$ & 0.18 & 0.19 & 0.16 & 0.24 & & & \\
\hline $\mathrm{Fe}_{2} \mathrm{O}_{3}$ & 1.37 & 1.85 & 1.25 & 1.01 & $1.50-4.50$ & & \\
\hline $\mathrm{Ni}_{2} \mathrm{O}_{3}$ & 0.02 & 0.01 & 0.01 & & & & \\
\hline $\mathrm{CuO}$ & 0.02 & 0.01 & 0.01 & 0.02 & & & \\
\hline $\mathrm{ZnO}$ & 0.30 & 0.23 & 0.39 & 0.50 & & & \\
\hline $\mathrm{Br} 2 \mathrm{O}$ & 0.01 & 0.01 & 0.01 & 0.02 & & & \\
\hline $\mathrm{SrO}$ & 0.12 & 0.12 & 0.11 & 0.13 & & & \\
\hline
\end{tabular}

447

448

449

Table 3- EDX Test Results of FBA Samples

\begin{tabular}{|c|c|c|c|c|}
\hline Elements & $\begin{array}{c}\text { FBA 1 } \\
\text { (wt \%) }\end{array}$ & $\begin{array}{c}\text { FBA 2 } \\
\text { (wt \%) }\end{array}$ & $\begin{array}{c}\text { FBA 3 } \\
\text { (wt \%) }\end{array}$ & $\begin{array}{c}\text { FBA 4 } \\
\text { (wt \%) }\end{array}$ \\
\hline $\mathrm{O}$ & 21.58 & 21.06 & 52.97 & 36.63 \\
\hline $\mathrm{K}$ & 4.78 & 3.92 & 7.02 & N/A \\
\hline $\mathrm{S}$ & 1.20 & 0.96 & 2.58 & 1.46 \\
\hline $\mathrm{Al}$ & 0.14 & 0.05 & 1.35 & 0.18 \\
\hline $\mathrm{P}$ & 0.26 & 0.12 & 0.64 & 0.25 \\
\hline $\mathrm{Cl}$ & 0.33 & $\mathrm{~N} / \mathrm{A}$ & 0.24 & N/A \\
\hline $\mathrm{Ca}$ & 7.11 & 4.70 & 26.44 & 10.11 \\
\hline $\mathrm{Si}$ & 0.36 & 0.25 & 4.59 & 0.45 \\
\hline $\mathrm{Mg}$ & 0.66 & 0.34 & 1.95 & 0.96 \\
\hline $\mathrm{Na}$ & 0.87 & 0.15 & 0.86 & 0.51 \\
\hline $\mathrm{C}$ & 62.65 & N/A & N/A & N/A \\
\hline $\mathrm{Fe}$ & N/A & N/A & 1.08 & 0.08 \\
\hline
\end{tabular}


Table 4- Typical Element Composition of Ash Sources of Pine Bark and Wood (Saarela et al. 2005)

\begin{tabular}{|l|l|l|l|l|l|l|l|l|l|}
\hline Elements & $\mathbf{S}$ & $\mathbf{C a}$ & $\mathbf{K}$ & $\mathbf{M g}$ & $\mathbf{P}$ & $\mathbf{F e}$ & $\mathbf{M n}$ & $\mathbf{A l}$ & $\mathbf{N a}$ \\
\hline $\begin{array}{l}\text { Bark } \\
(\%)\end{array}$ & N.A. & 0.7300 & 0.2500 & 0.1100 & 0.0650 & 0.0060 & 0.0900 & 0.0110 & 0.0096 \\
\hline $\begin{array}{l}\text { Wood } \\
(\%)\end{array}$ & N.A. & 0.0650 & 0.0430 & 0.0130 & 0.0040 & 0.0009 & 0.0200 & 0.0009 & 0.0032 \\
\hline
\end{tabular}

455

456

457 Table 5 - Elemental Mass Ratio of Potassium and Sodium in Forest Based Ash and a Comparison with Particle Size

\begin{tabular}{|c|c|c|c|c|}
\hline & FBA1 & FBA2 & FBA3 & FBA4 \\
\hline $\mathrm{Na}(\%)$ & 0.87 & 0.15 & 0.86 & 0.51 \\
\hline $\mathrm{K}(\%)$ & 4.78 & 3.92 & 7.02 & 0 \\
\hline Mole K/(Na+K) & 0.84 & 0.96 & 0.89 & 0.0 \\
\hline $\mathrm{K} / \mathrm{Na}$ & 5.50 & 26.10 & 8.20 & $\sim 0$ \\
\hline $\begin{array}{c}\text { Mean Particle } \\
\text { Size(Micro Meter) }\end{array}$ & $\sim 300$ & $\sim 1000$ & $\sim 1000$ & $\sim 400$ \\
\hline
\end{tabular}

Table 6- Fresh Properties of Concrete Mixtures

\begin{tabular}{|c|c|c|c|c|c|c|c|c|c|c|c|c|c|c|c|c|c|}
\hline & \multirow[t]{2}{*}{ Reference } & \multicolumn{4}{|c|}{ CFBA $1 \%$} & \multicolumn{4}{|c|}{ CFBA $2 \%$} & \multicolumn{4}{|c|}{ CFBA $3 \%$} & \multicolumn{4}{|c|}{ CFBA $4 \%$} \\
\hline & & 5 & 10 & 15 & 20 & 5 & 10 & 15 & 20 & 5 & 10 & 15 & 20 & 5 & 10 & 15 & 20 \\
\hline $\begin{array}{l}\text { Slump } \\
(\mathrm{mm})\end{array}$ & 27 & 24.0 & 33.0 & 32.5 & 33.0 & 49.0 & 35.0 & 27.0 & 25.0 & 40.0 & 30.0 & 27.0 & 27.0 & 25.0 & 20.0 & 27.0 & 20.0 \\
\hline $\begin{array}{l}\text { Air } \\
\text { Content } \\
(\%)\end{array}$ & 2.5 & 2.7 & 2.6 & 2.6 & 3.5 & 3.4 & 4.5 & 3.7 & 3.7 & 3.4 & 3.3 & 3.8 & 3.7 & 2.9 & 3.3 & 3.5 & 3.5 \\
\hline
\end{tabular}

460

461

462

Table 7- Compressive Strength of Concrete Mixtures

\begin{tabular}{|c|c|c|c|c|c|c|}
\hline \multirow{5}{*}{$\begin{array}{c}\text { Percentage } \\
\text { of FBA } \\
(\%)\end{array}$} & \multicolumn{5}{|c|}{ Average Compressive Strength [N/mm $\mathbf{~}^{2}$ (Std. Dev.) } \\
\cline { 3 - 7 } & & 1 Day & 3 Days & 7 Days & 14 Days & 28 Days \\
\hline \multirow{4}{*}{ CFBA1 } & 0 & $17.36(0.49)$ & $27.27(0.49)$ & $32.24(0.48)$ & $33.00(0.50)$ & $33.14(0.54)$ \\
\cline { 2 - 7 } & 5 & $11.75(0.22)$ & $20.36(0.21)$ & $25.00(0.25)$ & $31.74(0.24)$ & $27.92(0.23)$ \\
\cline { 2 - 7 } & 10 & $5.69(0.32)$ & $15.76(0.33)$ & $18.00(0.31)$ & $22.00(0.34)$ & $24.50(0.35)$ \\
\cline { 2 - 7 } & 15 & $13.00(0.4)$ & $17.00(0.43)$ & $23.82(0.41)$ & $26.74(0.45)$ & $28.57(0.47)$ \\
\cline { 2 - 7 } & 20 & $9.00(0.17)$ & $10.00(0.16)$ & $17.78(0.19)$ & $19.25(0.18)$ & $22.75(0.18)$ \\
\hline & 5 & $9.52(0.27)$ & $16.00(0.29)$ & $21.78(0.26)$ & $22.48(0.27)$ & $24.55(0.28)$ \\
\hline
\end{tabular}




\begin{tabular}{|c|c|c|c|c|c|c|}
\hline \multirow{3}{*}{ CFBA 2 } & 10 & $6.32(0.26)$ & $19.88(0.25)$ & $24.26(0.23)$ & $23.65(0.24)$ & $27.12(0.25)$ \\
\cline { 2 - 7 } & 15 & $15.31(0.35)$ & $16.60(0.32)$ & $20.50(0.33)$ & $22.55(0.3)$ & $23.50(0.37)$ \\
\cline { 2 - 7 } & 20 & $10.30(0.10)$ & $11.82(0.11)$ & $14.46(0.08)$ & $14.31(0.09)$ & $16.30(0.1)$ \\
\hline \multirow{4}{*}{ CFBA 3 } & 5 & $12.18(0.15)$ & $21.79(0.14)$ & $27.91(0.16)$ & $28.04(0.14)$ & $35.00(0.15)$ \\
\cline { 2 - 7 } & 10 & $11.50(0.32)$ & $23.57(0.33)$ & $25.35(0.32)$ & $29.60(0.31)$ & $31.72(0.32)$ \\
\cline { 2 - 7 } & 15 & $12.50(0.21)$ & $20.54(0.22)$ & $24.00(0.23)$ & $25.84(0.21)$ & $30.33(0.22)$ \\
\hline \multirow{3}{*}{ CFBA 4 } & 20 & $10.27(0.20)$ & $18.10(0.22)$ & $20.00(0.21)$ & $22.51(0.20)$ & $25.00(0.21)$ \\
\cline { 2 - 7 } & 10 & $14.00(0.14)$ & $28.00(0.16)$ & $31.00(0.15)$ & $34.00(0.14)$ & $42.50(0.15)$ \\
\cline { 2 - 7 } & 15 & $16.52(0.10)$ & $24.12(0.12)$ & $28.18(0.11)$ & $32.50(0.09)$ & $38.30(0.10)$ \\
\cline { 2 - 7 } & 20 & $14.81(0.14)$ & $24.70(0.14)$ & $27.00(0.13)$ & $29.83(0.15)$ & $29.00(0.14)$ \\
\hline
\end{tabular}


Table 8- Tensile Strength of Concrete Mixtures

\begin{tabular}{|c|c|c|c|c|c|c|}
\hline & \multirow{2}{*}{$\begin{array}{l}\text { Percenta } \\
\text { ge of } \\
\text { FBA }(\%)\end{array}$} & \multicolumn{5}{|c|}{ Average Tensile Strength $\left[\mathrm{N} / \mathrm{mm}^{2}\right]$ (Std. Dev.) } \\
\hline & & 1 Day & 3 Days & 7 Days & 14 Days & 28 Days \\
\hline \multirow{5}{*}{ CFBA 1} & 0 & $2.04(0.02)$ & $3.26(0.02)$ & $3.52(0.01)$ & $3.57(0.02)$ & $3.63(0.02)$ \\
\hline & 5 & $1.75(0.11)$ & $2.71(0.10)$ & $3.24(0.08)$ & $3.36(0.09)$ & $3.56(0.10)$ \\
\hline & 10 & $1.00(0.11)$ & $2.31(0.09)$ & $2.61(0.09)$ & $2.75(0.1)$ & $2.83(0.11)$ \\
\hline & 15 & $0.80(0.09)$ & $2.50(0.09)$ & $2.58(0.08)$ & $2.59(0.09)$ & $3.10(0.08)$ \\
\hline & 20 & $0.70(0.08)$ & $1.89(0.09)$ & $2.17(0.12)$ & $2.16(0.1)$ & $2.49(0.11)$ \\
\hline \multirow{4}{*}{ CFBA 2} & 5 & $1.38(0.10)$ & $2.48(0.12)$ & $2.58(0.10)$ & $2.93(0.09)$ & $2.97(0.11)$ \\
\hline & 10 & $1.59(0.02)$ & $2.98(0.01)$ & $2.43(0.02)$ & $2.97(0.01)$ & $2.96(0.02)$ \\
\hline & 15 & $1.84(0.05)$ & $1.87(0.05)$ & $2.62(0.04)$ & $2.68(0.06)$ & $2.28(0.05)$ \\
\hline & 20 & $1.41(0.08)$ & $1.65(0.09)$ & $2.33(0.11)$ & $2.19(0.1)$ & $1.80(0.12)$ \\
\hline \multirow{4}{*}{ CFBA 3} & 5 & $1.88(0.08)$ & $2.64(0.07)$ & $2.97(0.06)$ & $2.81(0.08)$ & $3.16(0.07)$ \\
\hline & 10 & $1.87(0.08)$ & $2.93(0.07)$ & $3.00(0.08)$ & $3.20(0.07)$ & $3.04(0.08)$ \\
\hline & 15 & $1.62(0.08)$ & $2.31(0.09)$ & $2.46(0.06)$ & $2.30(0.07)$ & $3.08(0.08)$ \\
\hline & 20 & $1.44(0.10)$ & $2.10(0.09)$ & $2.18(0.08)$ & $2.12(0.09)$ & $2.89(0.10)$ \\
\hline \multirow{4}{*}{ CFBA 4} & 5 & $1.61(0.10)$ & $2.81(0.11)$ & $2.67(0.11)$ & $3.22(0.10)$ & $3.61(0.12)$ \\
\hline & 10 & $1.67(0.10)$ & $2.64(0.12)$ & $2.89(0.11)$ & $3.15(0.10)$ & $3.63(0.12)$ \\
\hline & 15 & $1.40(0.10)$ & $2.43(0.09)$ & $2.54(0.12)$ & $2.91(0.11)$ & $3.34(0.11)$ \\
\hline & 20 & $1.53(0.08)$ & $2.34(0.09)$ & $2.74(0.07)$ & $2.96(0.08)$ & $3.49(0.07)$ \\
\hline
\end{tabular}

465

466

467 


\begin{tabular}{|c|c|c|c|c|c|c|c|c|}
\hline \multirow{2}{*}{$\begin{array}{l}\text { FBA } \\
(\%)\end{array}$} & \multicolumn{2}{|c|}{ CFBA 1} & \multicolumn{2}{|c|}{ CFBA 2} & \multicolumn{2}{|c|}{ CFBA 3} & \multicolumn{2}{|c|}{ CFBA 4} \\
\hline & $\begin{array}{c}\text { E(GPa) } \\
\text { (Std. Dev.) }\end{array}$ & $\begin{array}{c}\mu \\
\text { (Std. Dev.) }\end{array}$ & $\begin{array}{c}\text { E(GPa) } \\
\text { (Std. Dev.) }\end{array}$ & $\begin{array}{c}\mu \\
\text { (Std. Dev.) }\end{array}$ & $\begin{array}{c}\text { E(GPa) } \\
\text { (Std. Dev.) }\end{array}$ & $\begin{array}{c}\mu \\
\text { (Std. Dev.) }\end{array}$ & $\begin{array}{c}\text { E(GPa) } \\
\text { (Std. Dev.) }\end{array}$ & $\begin{array}{c}\mu \\
\text { (Std. Dev.) }\end{array}$ \\
\hline 0 & $\begin{array}{l}33.5 \\
(0.38)\end{array}$ & $\begin{array}{c}0.21 \\
(0.0005)\end{array}$ & $\begin{array}{l}33.5 \\
(0.38)\end{array}$ & $\begin{array}{c}0.21 \\
(0.0005)\end{array}$ & $\begin{array}{l}33.5 \\
(0.38)\end{array}$ & $\begin{array}{c}0.21 \\
(0.0005)\end{array}$ & $\begin{array}{c}33.5 \\
(0.38)\end{array}$ & $\begin{array}{c}0.21 \\
(0.0005)\end{array}$ \\
\hline 5 & $\begin{array}{l}20.3 \\
(0.37)\end{array}$ & $\begin{array}{c}0.20 \\
(0.0006)\end{array}$ & $\begin{array}{l}19.7 \\
(0.38)\end{array}$ & $\begin{array}{c}0.20 \\
(0.0005)\end{array}$ & $\begin{array}{l}22.2 \\
(0.39)\end{array}$ & $\begin{array}{c}0.20 \\
(0.0007)\end{array}$ & $\begin{array}{l}23.5 \\
(0.37)\end{array}$ & $\begin{array}{c}0.20 \\
(0.0006)\end{array}$ \\
\hline 10 & $\begin{array}{c}16.1 \\
(0.46)\end{array}$ & $\begin{array}{c}0.14 \\
(0.0008)\end{array}$ & $\begin{array}{l}20.3 \\
(0.4)\end{array}$ & $\begin{array}{c}0.18 \\
(0.0007)\end{array}$ & $\begin{array}{c}17.9 \\
(0.38)\end{array}$ & $\begin{array}{c}0.19 \\
(0.0006)\end{array}$ & $\begin{array}{l}20.2 \\
(0.39)\end{array}$ & $\begin{array}{c}0.17 \\
(0.0005)\end{array}$ \\
\hline 15 & $\begin{array}{c}18.3 \\
(0.42)\end{array}$ & $\begin{array}{c}0.17 \\
(0.0007)\end{array}$ & $\begin{array}{l}16.8 \\
(0.41)\end{array}$ & $\begin{array}{c}0.16 \\
(0.0005)\end{array}$ & $\begin{array}{l}19.2 \\
(0.4)\end{array}$ & $\begin{array}{c}0.21 \\
(0.0006)\end{array}$ & $\begin{array}{l}19.3 \\
(0.39)\end{array}$ & $\begin{array}{c}0.22 \\
(0.0005)\end{array}$ \\
\hline 20 & $\begin{array}{c}18.4 \\
(0.39)\end{array}$ & $\begin{array}{c}0.19 \\
(0.0006)\end{array}$ & $\begin{array}{c}13.6 \\
(0.38)\end{array}$ & $\begin{array}{c}0.16 \\
(0.0007)\end{array}$ & $\begin{array}{c}18.4 \\
(0.39)\end{array}$ & $\begin{array}{c}0.19 \\
(0.0007)\end{array}$ & $\begin{array}{l}18.5 \\
(0.4)\end{array}$ & $\begin{array}{c}0.20 \\
(0.0008)\end{array}$ \\
\hline
\end{tabular}

470

471

472

473

474 


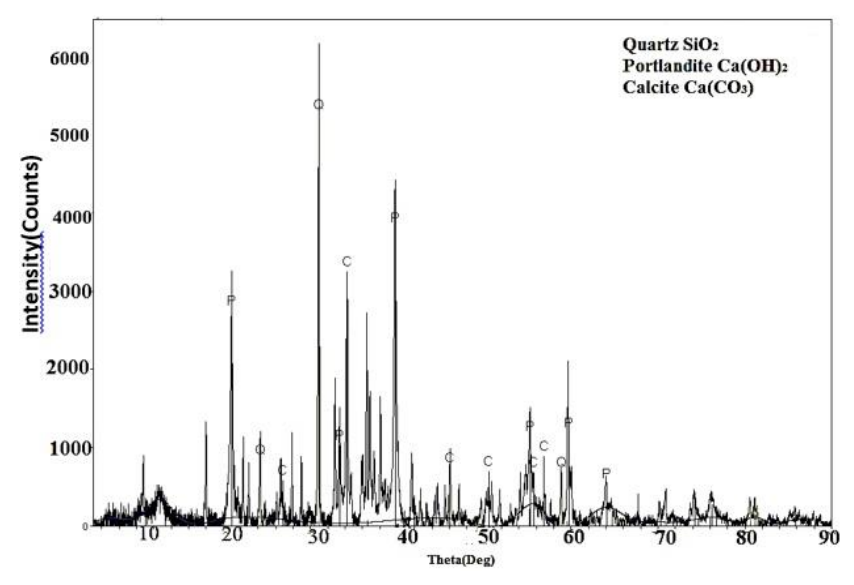

Fig1a-FBA 1

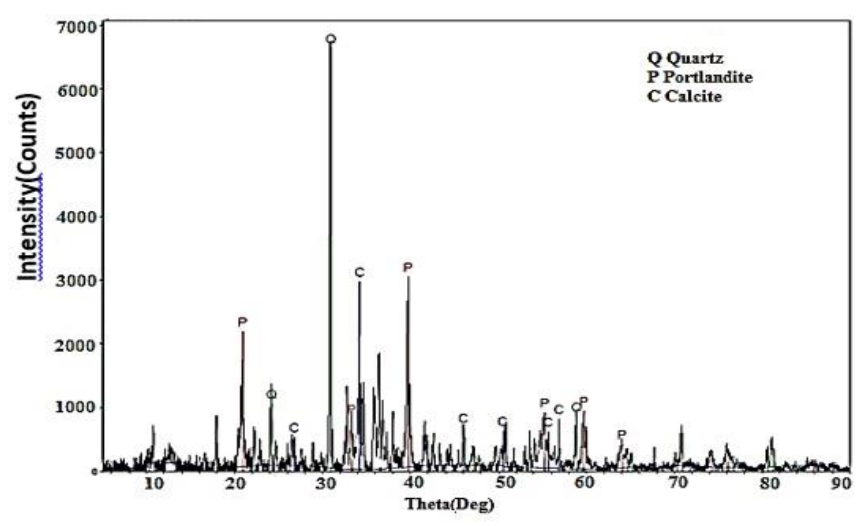

Fig1c-FBA 3

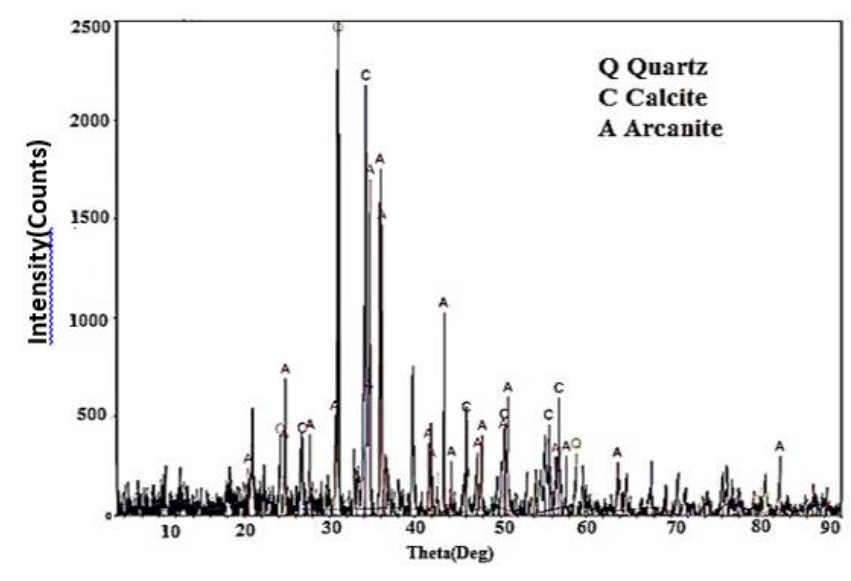

Fig1b-FBA 2

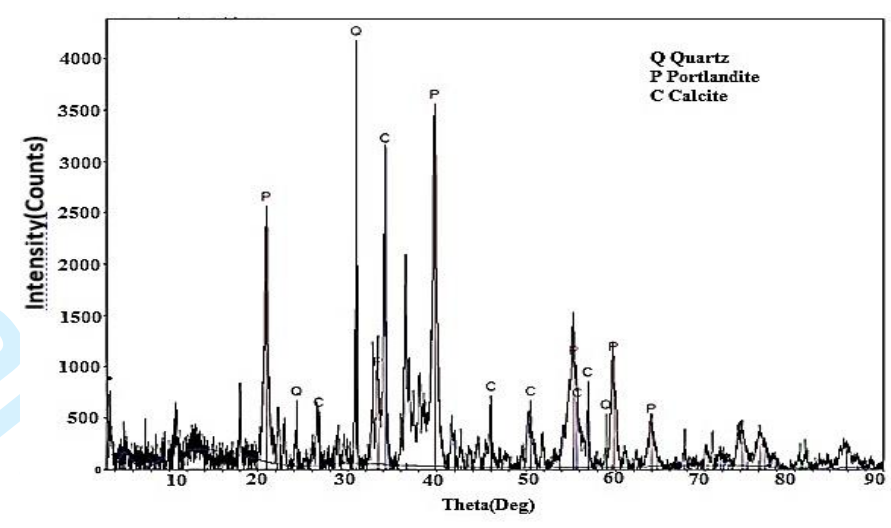

Fig1d-FBA 4 


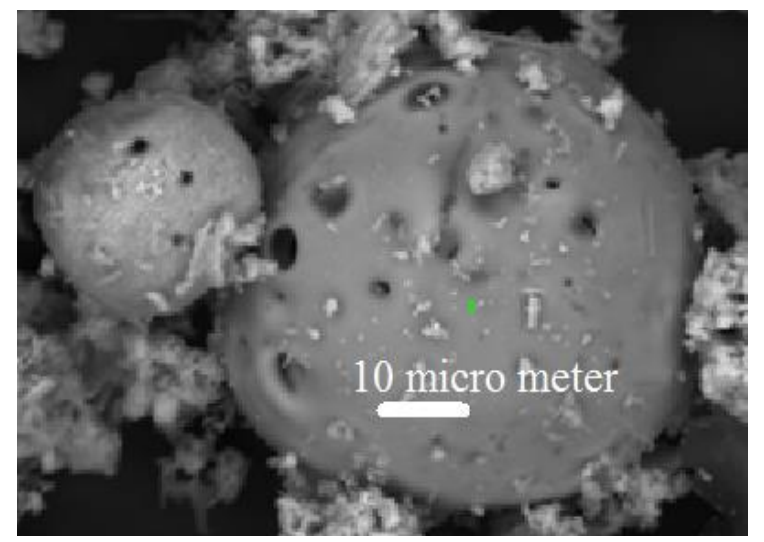

Fig 2a-FBA 1

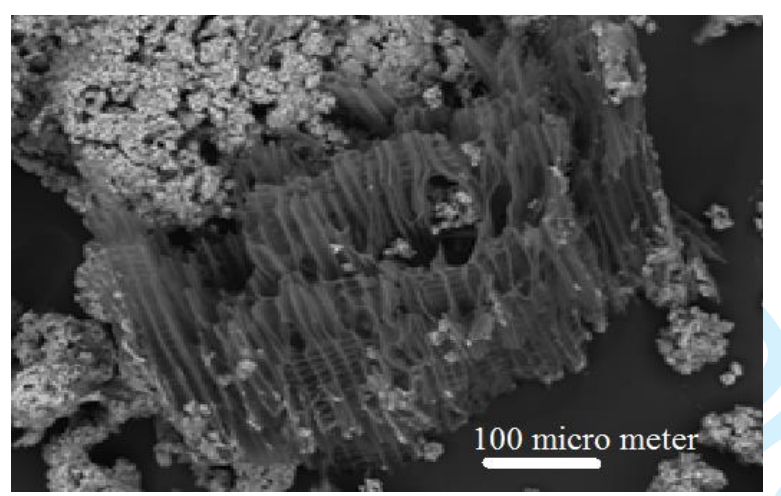

Fig 2c-FBA 3

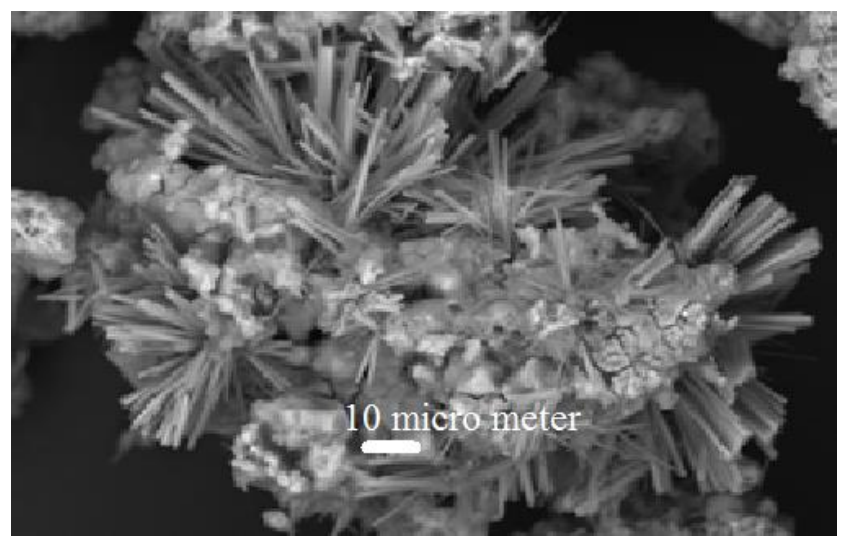

Fig 2b-FBA 2

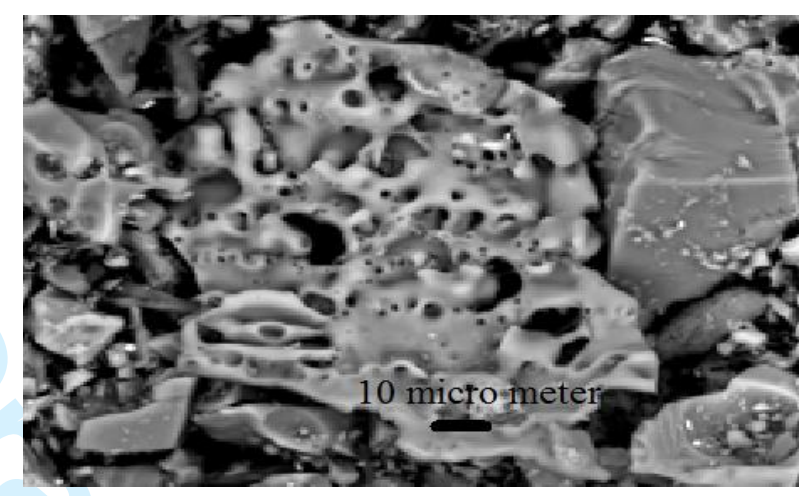

Fig 2d-FBA 4 


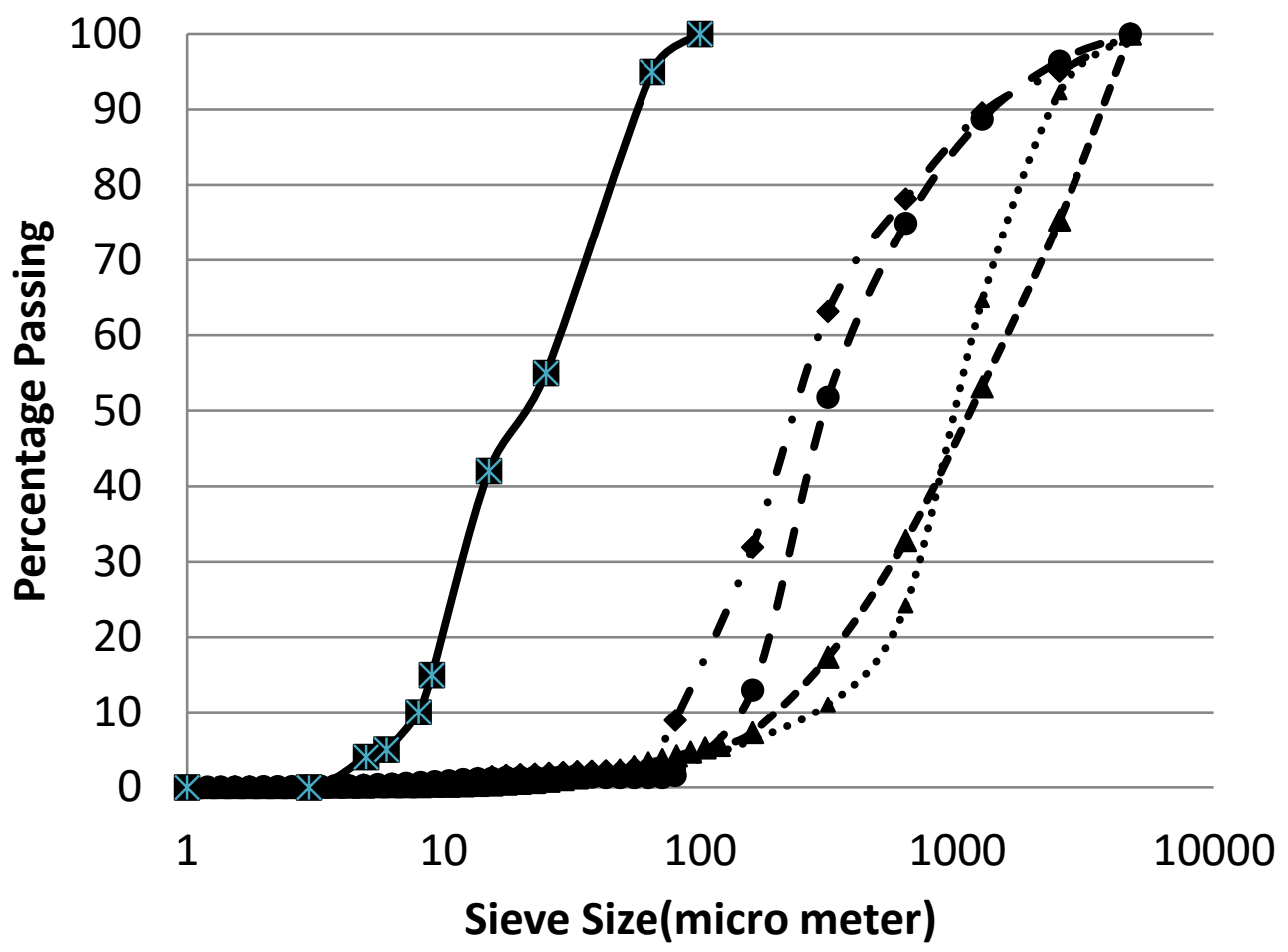




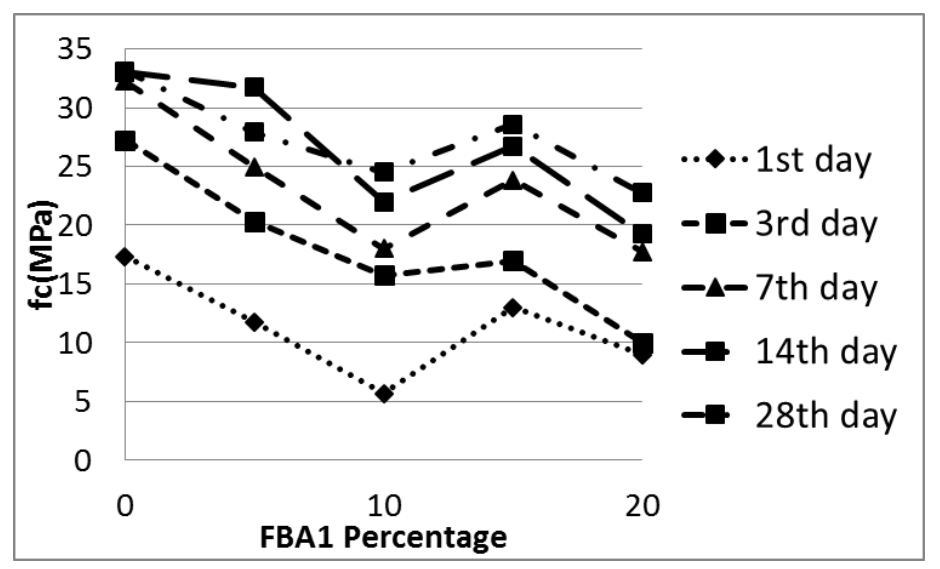

Fig 4a-CFBA 1

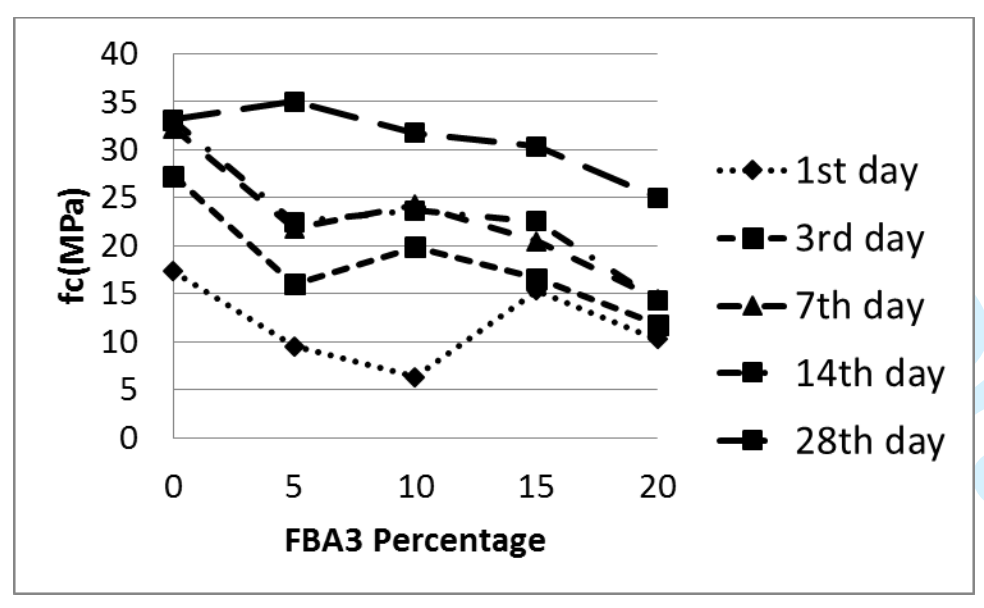

Fig 4c-CFBA 3

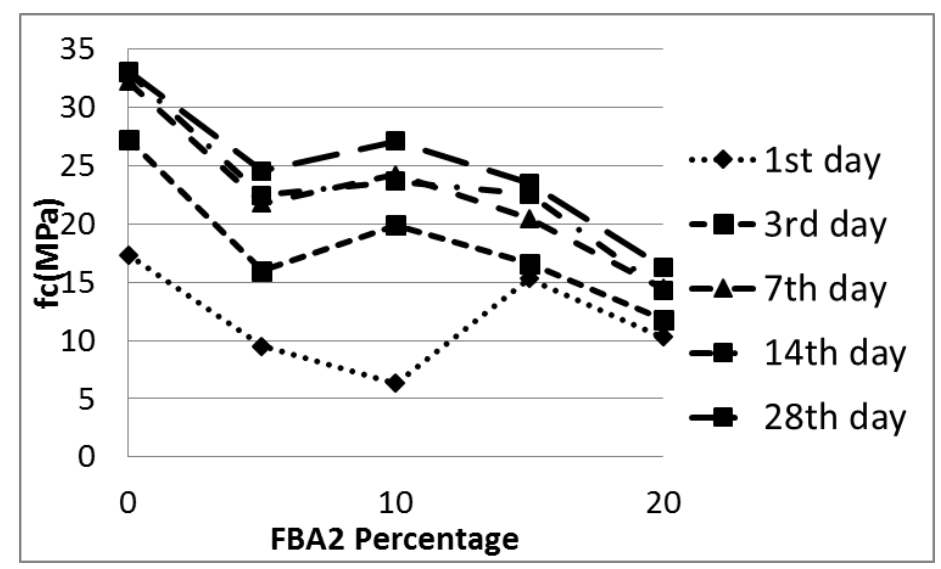

Fig 4b-CFBA 2

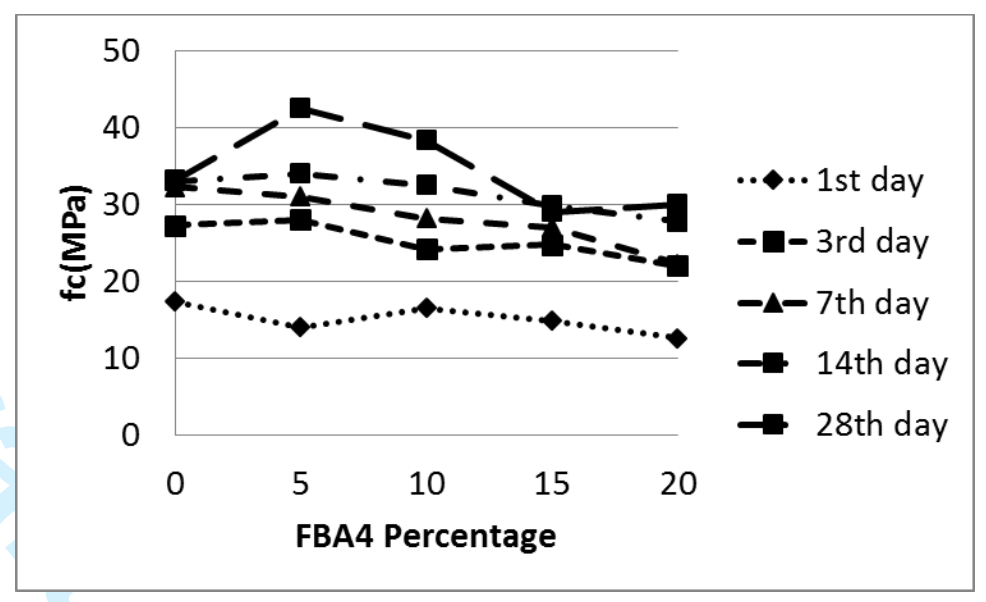

Fig 4d-CFBA 4

Figure 4- Development of Compressive Strength over 28 days in Mixtures Containing a) FBA 1; b) FBA 2; c) FBA 3 and d) FBA 4 


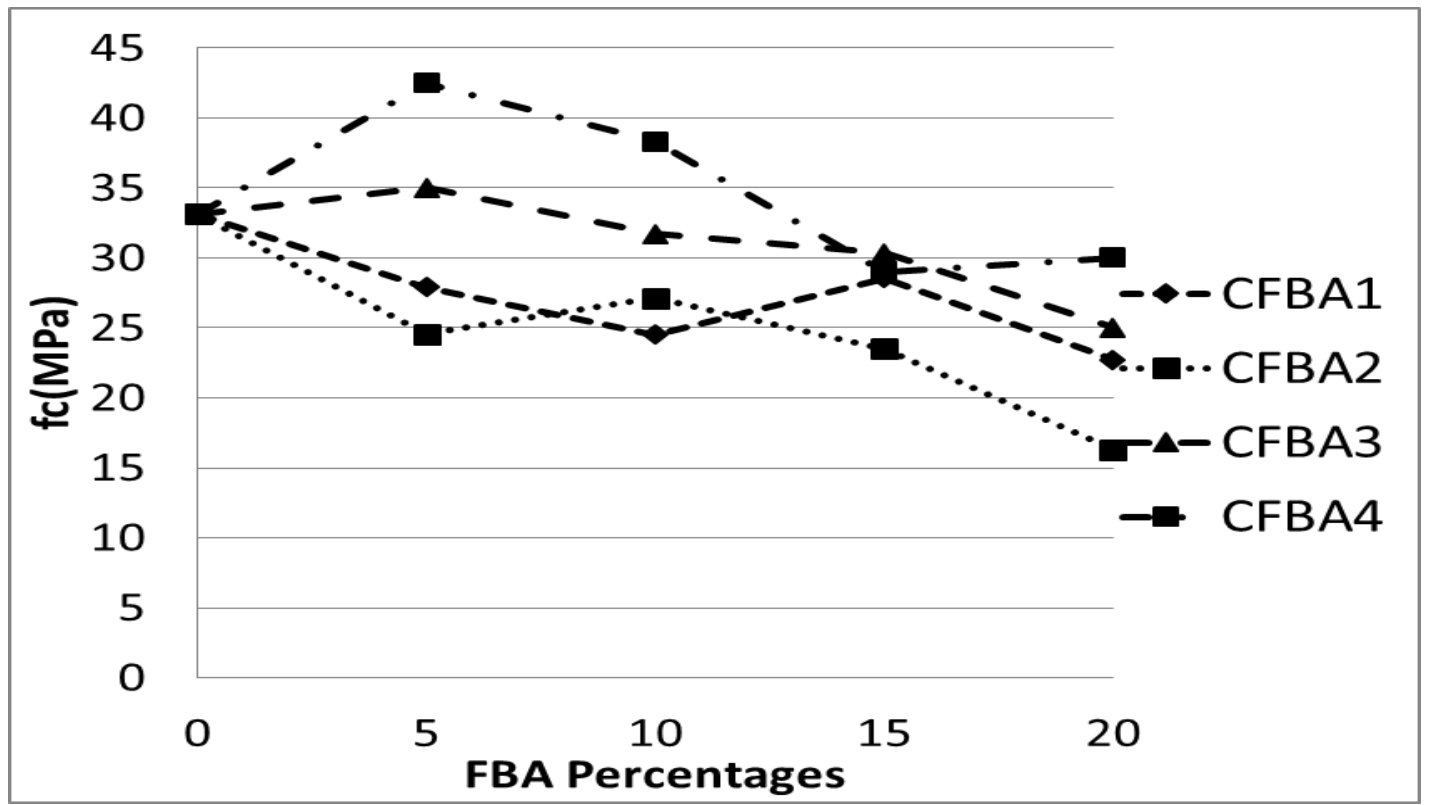

Figure 5- Variation of 28 Days Compressive Strength of Concretes with Different Ash Samples 


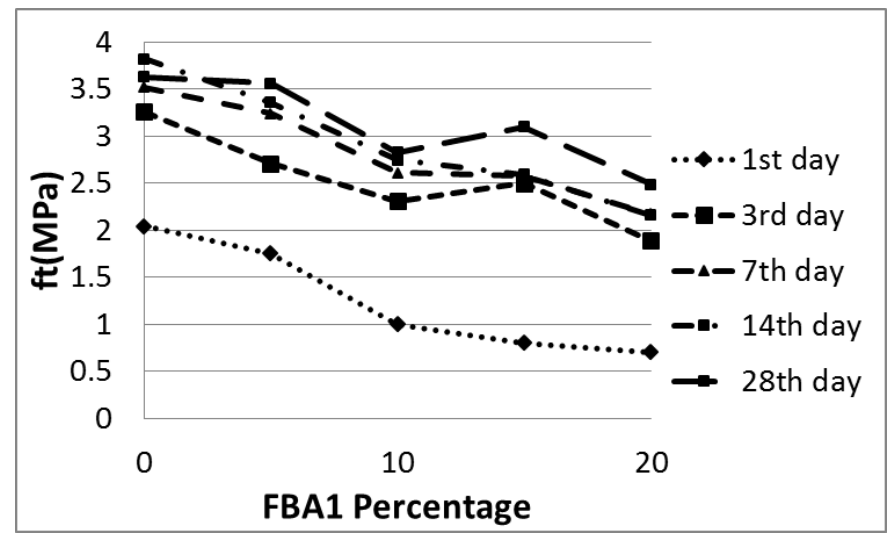

Fig 6a- CFBA 1

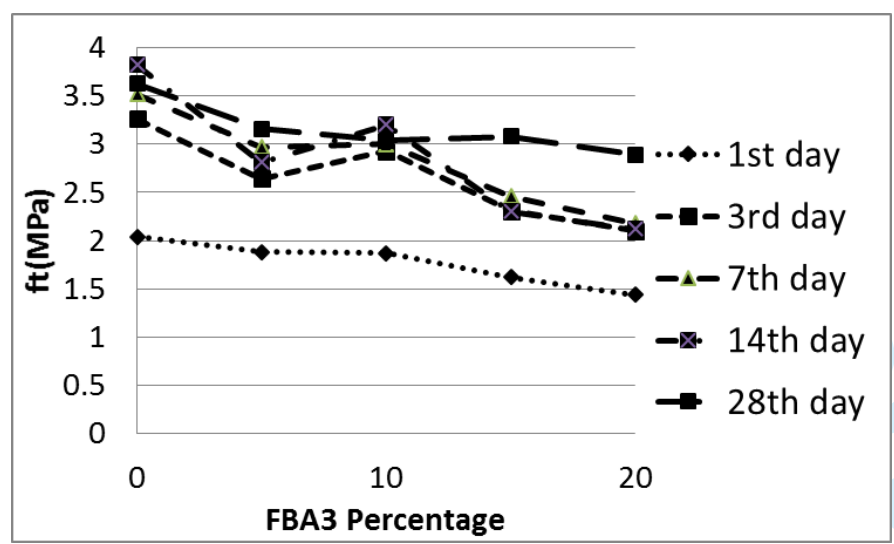

Fig 6c- CFBA 3

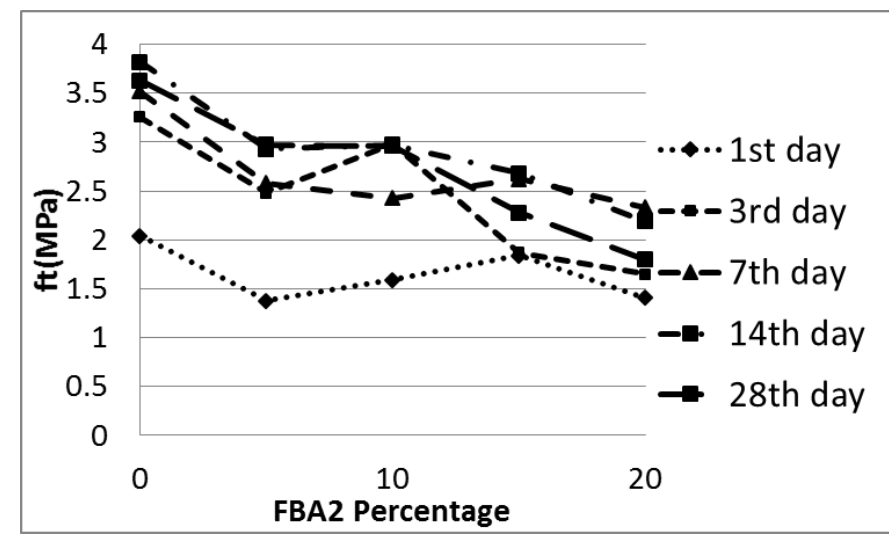

Fig 6b- CFBA 2

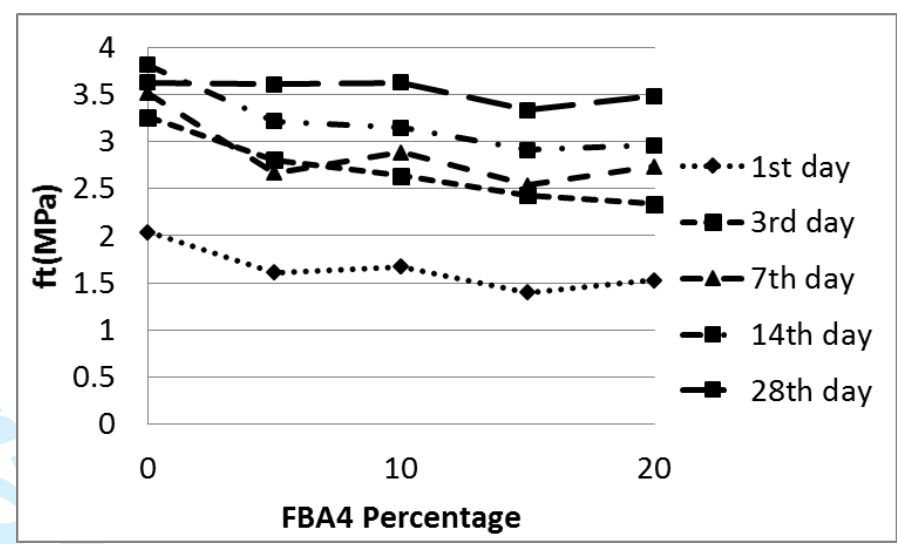

Fig 6d- CFBA 4
489

490

491
Figure 6- Development of Tensile Strength over 28 days in Mixtures Containing a) FBA 1; b) FBA 2; c) FBA 3 and d) FBA 4 


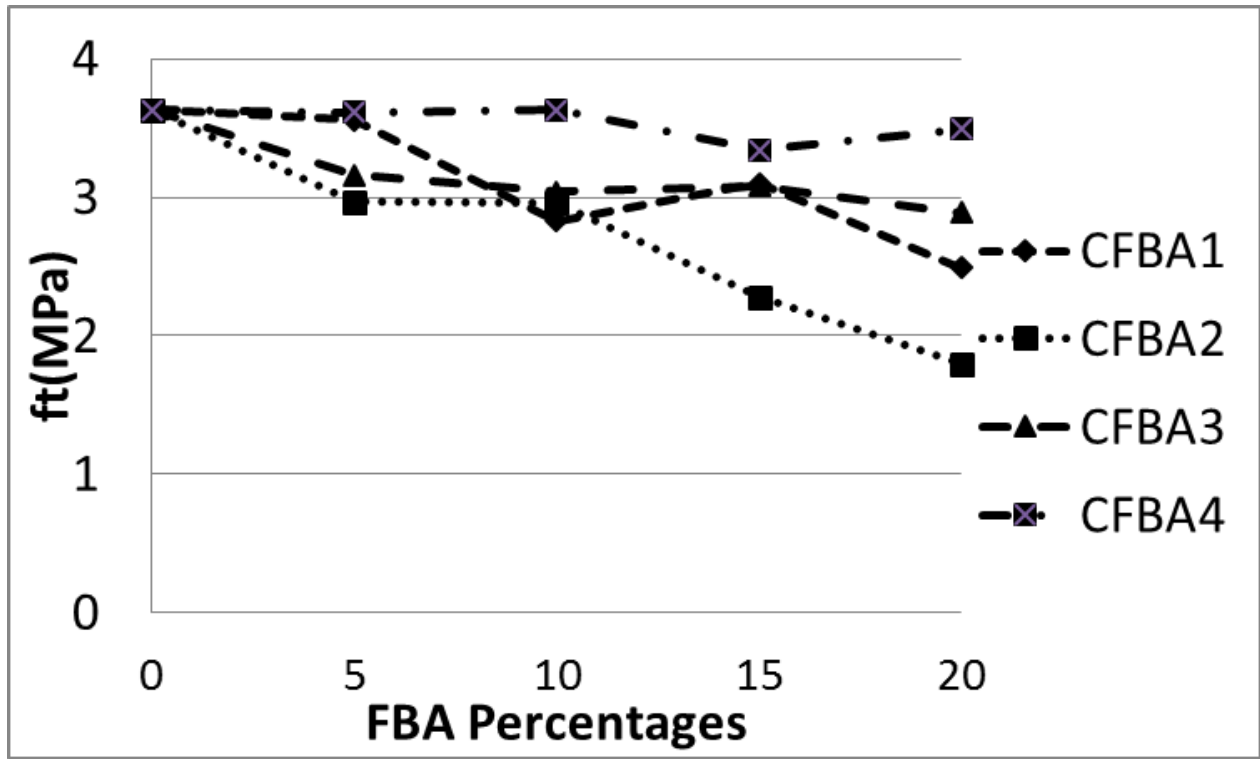

Figure 7- Variation of 28 Days Tensile Strength of Concretes with Different Ash Samples

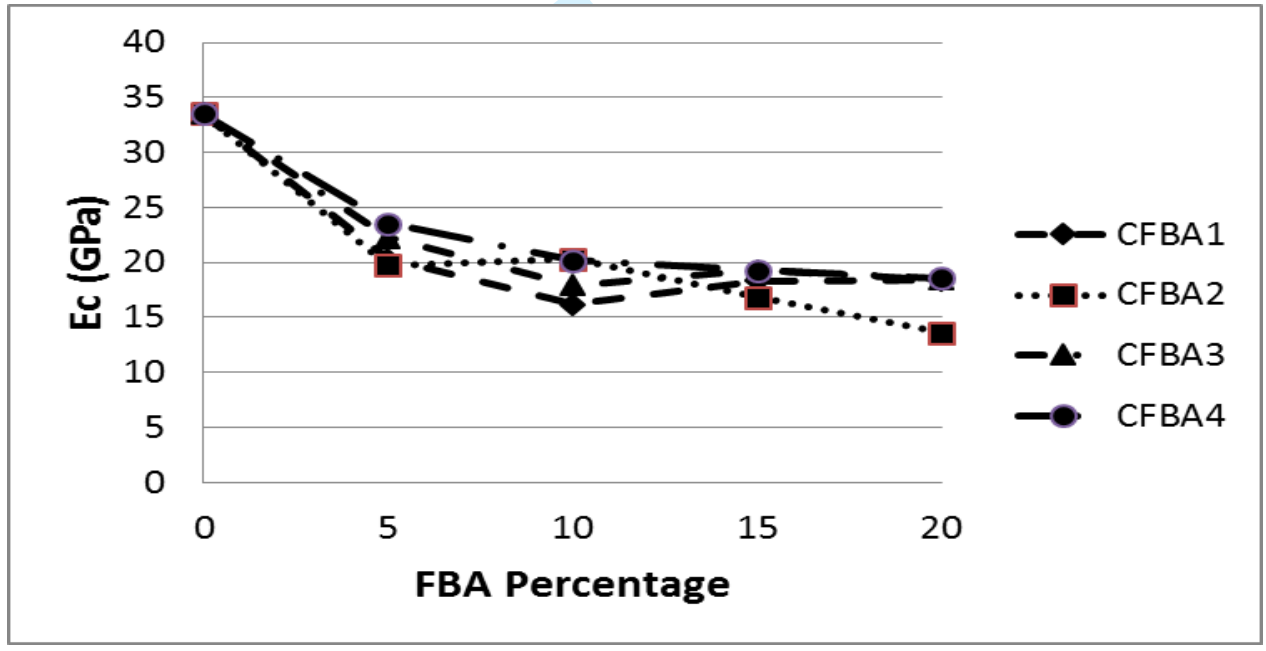

